\title{
Gluconobacter in biosensors: applications of whole cells and enzymes isolated from Gluconobacter and Acetobacter to biosensor construction
}

\author{
Juraj Švitel · Jan Tkáč · Igor Voštiar · \\ Marian Navrátil · Vladimír Štefuca · \\ Marek Bučko · Peter Gemeiner
}

Published online: 6 February 2007

(C) Springer Science+Business Media B.V. 2007

\section{Erratum to: Biotechnol Lett (2006) 28: 2003-2010 DOI 10.1007/s10529-006-9195-3}

There were spelling errors in the title of the original publication.

The online version of the original article can be found at http://dx.doi.org/10.1007/s10529-006-9195-3

\section{J. Švitel $(\bowtie) \cdot$ M. Navrátil}

Institute of Biotechnology and Food Science, Faculty of Chemical and Food Technology, Slovak University of Technology, Radlinského 9, SK 81237 Bratislava, Slovakia

e-mail: juraj.svitel@gmail.com

J. Tkáč · M. Bučko · P. Gemeiner Institute of Chemistry, Slovak Academy of Sciences, Dúbravská cesta 9, SK 84538 Bratislava, Slovakia

I. Voštiar

Cell Biology and Biochemistry, Pacific Northwest National Laboratories, 902 Battelle Blvd., Richland, WA 99354, USA

V. Štefuca

Institute of Chemical and Environmental

Engineering, Faculty of Chemical and Food

Technology, Slovak University of Technology,

Radlinského 9, SK 81237 Bratislava, Slovakia

Present Address:

M. Navrátil

Department of Chemistry, University of Minnesota, 207 Pleasant St. SE, Minneapolis, MN 55455, USA 